\title{
Culture and Fashion Styles: do They Co-Exist in Women's Fashion Magazines? an Explorative Investigation from New York, London and Bangkok
}

\author{
Rujirutana Mandhachitara* \\ Pennsylvania State University, USA
}

*Corresponding author: Rujirutana Mandhachitara, Department of Business Administration, Pennsylvania State University, New Kensington, Pennsylvania, USA.

Received Date: September 05, 2018

Published Date: September 12, 2018

\section{Introduction}

Although print media has recently lost its traction due to the popularity of e-reader and online medium, women's fashion magazines seem to find their positioning and are expand internationally to capture a larger subscription. They are still widely seen in the waiting rooms of your professional offices. They still serve as a source of fashion trend, lifestyles and social tips. As I teach global marketing, I tell my students about "think global, act local" strategy adopted by corporations. Additionally, I am a travel fanatic and passionate about research in fashion. Then I began to wonder if this "think global, act local" strategy could be true in the case of women's fashion magazines and their photographic images of fashion clothing.

My investigation aims to examine the specific manifestations of clothing and fashion images portrayed in women's fashion magazines from New York, London and Bangkok. These three metropolitan cities are not only considered as the fashion hubs in three continents, they also represent different degree of individualistic and collectivistic cultural orientation. Using a quantitative approach of content analysis, I was able to statistically compare the photographic images to draw meaningful conclusion.

\section{History of Women's Fashion Magazines}

Women's magazines can be classified as health and beauty, home, grooming, lifestyles and fashion [1]. They play important roles as major marketing sources for advertising, product information, personal and professional tips. They serve as guides for women on behavior and duties; women were encouraged to take action on social ills and get involved in women's movements [2]. They educate women on social and health issues pertaining to their lifestyle. Magazines bring issues such as sexual dangers to women and create general public awareness. Some scholars even credit current magazines with teaching women to take charge of their own health and learn to value themselves, thus giving them a sense of empowerment [3].

Most of the magazines that are on newsstands today, though, did not launch until after World War II, as changes occurred that reflected both industry and society trends. The roles of women were changing, and the magazines paralleled this change by reflecting a wider range of interests. More women were in the workforce, selfsufficient and taking on new hobbies, so to meet these interests the magazines picked up new subject matter [3]. Moeran B [4] suggest that magazine editors portray models and celebrities wearing the latest fashion trends so that magazine consumers will then establish the latest fashions as the ideal fashion image and will purchase the designer trends or, at least, less expensive versions of them. Moeran's assessment of fashion magazine content as a vehicle to present designer fashions to the consumers of fashion magazines shows the influence and importance of fashion magazines in the greater fashion system [4].

Today's publications reflect yet another cultural shift away from domestic life and more focused on fashion, beauty, relationships and everyday tips [5]. It is important that fashion magazine content not only provide information on the latest trends and news in fashion, but also incorporate additional information for readers, including advertisements, photographs, and surveys, as well as information on clothing, cosmetics, accessory venues, and fashion forecasts. Hence, contents of fashion magazines can be classified into three main categories, i.e., reader surveys, fashion forecasts of colors and styles for upcoming seasons and pictures of current fashions accompanied by editorial credits, including a list of manufacturers and retailers that supply the fashions. 
Presently women's magazines target niche market and loyal subscribers. For example, Shape is geared toward physical fitness, while Cosmopolitan dishes on the latest dating and fashion tips. Vogue, published in December 1892, provides information on the latest trends in "high-fashion, art, and photography" while simultaneously running advertisements for ready-to-wear clothing. Harper's Bazaar is “the first American women's magazine that focused primarily on fashion" [6]. In Style blends fashion and celebrity lifestyles. Lucky focuses on shopping and retail venues. Glamour differentiates itself with the Women of the Year Award and social responsibility focus.

\section{Impact of Culture and images in Fashion Magazines}

Culture is an important concern in international business operations. A broadly defined, national culture of values, beliefs, norms, and behavioral patterns of a national group influences major business activities. The dichotomies like individualism/ collectivism [7] and independence/interdependence [8] are overwhelmingly adopted to examine differences across cultures. This line of research holds that Thai is collectivistic and hierarchical while US and UK are individualistic [9]. Cross-cultural research commonly polarizes cultures and associates them with respective geographic areas [10].

When visual images depict beautiful endorsers, consumers tend to evaluate brand attributes better [11]. Reichert $\mathrm{T}$, et al. [12] conclude that endorsers with convincing sex appeal is able to provoke a second look, then enhances recall, forms focal points of discussion, leads to interest in new trends or fashions, and results in complete identification of the endorser. With the tendency that women's fashion magazines portraying nearly unachievable thinness of women, a widely criticized comment is addressed toward body dissatisfaction [13]. Lin and Yeh examine the physical attractiveness of female models in Taiwanese advertisings. They find that most advertising endorsers were celebrities with fit bodies and pleasant expressions.

In western culture, gender stereotyping in advertising is prevalent. Highly sexualized objectification of women in media images is widespread [14]. Kilbourne comment that "graphic sexual images seem more extreme, more pervasive and more perverse than before." Nudity and revealing clothing in fashion magazines are ubiquitous [15]. Dianoux C and Linhart Z [16] find that women in three European countries have more negative attitudes than men toward advertisement and product with women nudity is used [16]. Consumers, however, appear increasingly tolerant of this form of communication. A content analysis of nearly 2,000 advertisements in 58 popular U.S. magazines resulted in, on average, one in every two advertisements portraying women as sex objects [14]. A content analysis of advertisements from Australian and Croatian magazines reveal that Croatian advertisements adopt both emotional appeals and informational cues [17].

Zimmerman A et al. [18] show that American women are less offended by advertisements with sexual connotations than before. Nelson MR, et al. [19] review advertisements published in seven editions of Cosmopolitan and find significant differences between advertisements in France and Thailand, which contain a great deal of sexual content, and the USA, Brazil, Korea, and China, for which the advertisements contain less sexual content.

In the eastern culture, a study of visual images in Indonesia by Sugiarto $\mathrm{C}$ et al. [20] conclude that sexually appeal images are still taboo in Indonesia and other Asian countries. Liang B, et al. [21] collect 286 advertisements from 36 Chinese magazines and 775 ads from 32 US magazines in 17 categories. Using content analysis, Chinese magazines tend to use contextualized ads while westerners prefer non-contextualized advertisements. Additionally, the impact of culture on advertising is found to be moderated by product class (goods vs service), product category, and magazine category.

\section{Research Methodology}

Twenty women's fashion magazines, all published during the month of June, were included in the content analysis to establish the homogeneity or heterogeneity of fashion clothing trends across different cultures. Prior to content analysis, coding schemes must be created, which include a codebook and a coding form, describing all variables to be measured in detail [22]. Seven magazines, i.e., Elle, Cosmopolitan, Marie Claire, Vogue, Bazaar, In Style and Glamour were presented in both New York and London. The selection of equivalent Thai magazines was based on their positioning, target reader and subscription rate (REF). Bangkok magazines include Praew, Cleo, Dichan, Priew, Ploy Gam Petch and Lips. The number of pages of each country magazine vary. The US magazines range from 196 (Glamour) to 295 (In Style). The UK magazines contain 187 ((In Style) to 305(Glamour) pages. And the Thai magazines have the greatest number of pages among the three countries; 247 (Lips) to 385 (Cleo) pages.

Three trained coders evaluated the photographic clothing images with the percentage of agreement among the coders or inter-rater reliability to ensure data consistency should exceed 86 per cent [23]. Each image was selected randomly by rolling a die. The number of images investigated from the three-country magazines are 1,076 with US magazines consisting of 184 images, UK magazines have 412 images and Thai magazines have 480 images.

\section{Findings and General Discussions}

\section{Magazines characteristics}

Fashion trends and advertisement pages are commonly appeared in the US (45 and 23 per cent) and UK (49 and 27 per cent). Images portrayed by professional models are found 32 per cent in the US and 44 per cent in the UK magazines. Thai magazines tend to use common persons (37 per cent), celebrity (31 per cent) and professional models (29 per cent). The three-country magazines use persons with roughly around 25 years old, slightly older than research by Zhang L et al. [24]. The US magazines portray their photographic images with the beach background ( 9 per cent), while both UK and Thai magazines tend to shoot the images in the studios (37 and 30 per cent respectively).

\section{Clothing attributes}

About 20 per cent of the general attire are casual wears and summer dresses in all three-country magazines. Cocktail dresses 
also appear about 14 per cent of the images in the US and Thai magazines. Not surprisingly, the majority of all the magazines contain no jacket. If jackets are presented, they are either singlebreasted or open-front cardigan. White, plain and stretchy are popular in the June edition of all magazines. Due to the summer month, clothing comes in light color at about 33 to 44 per cent in all three-country magazines. The necklines for US and Thai magazines are $\mathrm{V}$, round and square and are found at 20 per cent. Cowl neck is a second most common style. The attire tends to be loose with no sleeves in Thailand and UK; the US magazines have long sleeves.
About 20 per cent of the Thai and UK magazines contains straight skirts and about 10 per cent are full skirts. The skirts in UK and US magazines are short and knee-length skirt is more common in Thai magazines. Styles of pants are quite different among the three-country magazines. The US magazines portray hot pants, skinny/legging in UK magazines and long straight pants in Thailand. Cotton and stretchy texture are commonly found. The bottom part of US magazines tends to be dark while the UK and Thai magazines are lighter. Black and white are trendy across all three-country magazines. Table 1 illustrates the clothing attributes and how they differ in the fashion magazines.

Table 1: The highest frequency of clothing attributes and chi-square analysis.

\begin{tabular}{|c|c|c|c|c|}
\hline & US & UK & TH & X2 (sig) \\
\hline Attire & Casual but stylish (18) & Summer dress (14) & Casual but stylish (15) & $137.76(0.00)$ \\
\hline Silhouette & Cocktail (14) & Summer/outdoor (14) & Casual (15) & $80.20(0.00)$ \\
\hline Jacket & No jacket (52) & No jacket (45) & No jacket (79) & 10.69 (ns) \\
\hline Jacket style & Single-breasted (5) & Single-breasted (6) & Open-front (7) & $60.99(0.00)$ \\
\hline Type of top & Casual blouse (11) & Casual blouse (8) & Casual blouse (15) & $57.95(0.00)$ \\
\hline Dress styles & Plain (21) & Plain (28) & Plain (35) & \\
\hline Texture of top & Stretched (18) & Sheer (17) & Stretched (40) & $76.82(0.00)$ \\
\hline Top mixed color & One color (48) & One color (46) & One color (59) & $6.95(\mathrm{~ns})$ \\
\hline Top first color & White (19) & White (20) & White (22) & $96.88(0.00)$ \\
\hline Color scheme & Light (33) & Light (30) & Light (44) & $22.34(0.00)$ \\
\hline Neckline & $\mathrm{V}(20)$ & Cowl (21) & $\mathrm{V}(27)$ & $68.73(0.00)$ \\
\hline Sleeves & Long (22) & Sleeveless (18) & Sleeveless (21) & $121.47(0.00)$ \\
\hline Type of skirt & Full (11) & Straight (20) & Straight (22) & $61.48(0.00)$ \\
\hline Skirt length & Above the knees (12) & Short (11) & Knee (7) & $32.39(0.01)$ \\
\hline Type of pants & Hot pants (5) & Legging (5) & Long straight (5) & $45.69(0.01)$ \\
\hline Style of bottom & Same as tops (36) & Same as tops (38) & Plain (27) & $80.88(0.00)$ \\
\hline Texture of bottom & Cotton (25) & Cotton (27) & Stretched (26) & $54.41(0.00)$ \\
\hline Bottom mixed color & One color (47) & One color (45) & One color (53) & $15.33(0.05)$ \\
\hline Bottom first color & White (17) & Black (16) & Black (18) & $41.64(0.07)$ \\
\hline Bottom color scheme & Dark (27) & Light (23) & Light (25) & $12.97(0.04)$ \\
\hline
\end{tabular}

\section{Revelation of body parts}

Although the results from ANOVA show that the three-country magazines differ in their degree of body parts revelation and the overall sexiness of top and bottom attires, the means rest around "little revealing". The UK magazines are evaluated to be more revealing overall than the US and Thai magazines. Additionally, the UK magazines reveal more thighs than US and Thai (magazines. The three-country magazines do not differ in showing the midriff. Table 2 illustrates the ANOVA results.

Table 2: Means and ANOVA results.

\begin{tabular}{|c|c|c|c|c|}
\hline Characteristics & US & UK & Thai & F (sig) \\
\hline Breast revealing & 1.51 & 1.62 & 1.44 & $4.63(0.01)$ \\
\hline Midriff revealing & 1.27 & 1.29 & 1.25 & $0.32(\mathrm{~ns})$ \\
\hline Overall dress revealing & 1.71 & 2.07 & 1.64 & $25.83(0.00)$ \\
\hline Thighs revealing & 1.89 & 2.14 & 1.78 & $6.18(0.00)$ \\
\hline Buttocks revealing & 1.03 & 1.14 & 1.08 & $3.25(0.04)$ \\
\hline Overall bottom attire revealing & 1.73 & 2.21 & 1.62 & $28.99(0.00)$ \\
\hline
\end{tabular}

1 (not at all revealing) to 5 (almost entirely revealing)

\section{Universal evaluation of clothing characteristics}

According to Table 3 below, the only insignificant mean differences among the eight-clothing style characteristic is the punk/rock. This means that summer cloth collection for all threecountry magazines do not emphasize the punk/rock style. The three most important style characteristics are neat, stylish and sexy. The images from UK magazines are perceived to be neater than those of US and Thai magazines. The UK magazines are more stylish than US and Thai magazines. Although the means of sexy style lean toward the "not too sexy", the photographic clothing images of UK magazines are still sexier than those of US and Thai.

Table 3: Means and ANOVA results

\begin{tabular}{|c|c|c|c|c|}
\hline Characteristics & US & UK & Thai & F (sig) \\
\hline Characteristics & US & UK & Thai & F (sig) \\
\hline Elegant & 3.53 & 3.28 & 3.31 & $5.09(0.01)$ \\
\hline Stylish & 2.99 & 2.18 & 2.34 & $55.21(0.00)$ \\
\hline Conservative & 2.7 & 2.99 & 2.63 & $15.26(0.00)$ \\
\hline Sexy & 3.14 & 2.49 & 2.76 & $32.43(0.00)$ \\
\hline
\end{tabular}




\begin{tabular}{|c|c|c|c|c|}
\hline Neat & 2.5 & 1.63 & 2.09 & $92.74(0.00)$ \\
\hline Extraordinary & 3.73 & 3.62 & 3.48 & $8.61(0.00)$ \\
\hline Flashy & 3.83 & 3.75 & 3.48 & $24.21(0.00)$ \\
\hline Punk & 3.92 & 3.84 & 3.89 & $2.34(\mathrm{~ns})$ \\
\hline
\end{tabular}

1 (extremely well) to 4 (not well at all)

\section{Closing Remark}

My examination shows that general fashion clothing attributes tends to conform across three geographical locations. What is popular in New York and London are transmitted to Bangkok. Global fashion brands targeting and advertising in these markets can utilize the economy of scale and their "think global" standardization strategy on their clothing attributes. However, the global fashion brands should pursue more "act local" adaptation strategy on how much their merchandise reveal the body parts of their wearers. Such obvious body part revelation in fashion is still narrowly accepted in a more collectivist-leaning eastern country like Thailand, though it has becoming more and more westernized. I believe that the most challenging task for global fashion brands is to find the mix strategy to balance fashion clothing manifestations with the unique cultural norms from the western and eastern cultures. Global fashion brand marketers and magazine publishers should assess their interpretive strategies to collage the three most important style characteristics identified in this research i.e., neat, stylish and sexy in their photographic images of fashion clothing. Again, how each style characteristic is translated onto fashion clothing should consider the cultural norms in each country location.

\section{References}

1. Xiaowei H (2013) A critical study of the contradictory role of women's magazines. Canadian Soc Sci 9(4): 184-205.

2. Zuckerman ME (1998) A history of popular women's magazines in the united states 1792-1995. Greenwood Press, USA, p. 272.

3. Zuckerman ME (1998) Sources on the history of women's magazines in the United States 1792-1995. Greenwood Press, USA.

4. Moeran B (2006) More than just a fashion magazine. Curr Sociol 54 (5): 725-744.

5. Baumgardner J, Richards A (2000) Manifesta: young women, feminism, and the future. Farrar, Straus and Giroux Publisher, Newyork, USA.

6. Hill DD (2004) As seen in vogue: a century of American fashion in advertising. Texas Tech University Press, Lubbock, USA, p. 238.
7. Triandis HC (2001) Individualism-collectivism and personality. J Pers 69 (6): $907-924$

8. Markus HR, Kitayama S (1991) Culture and the self: implications for cognition, emotion, and motivation. Psychol Rev 98(2): 224-253.

9. Hofstede G (1984) Culture's consequences: International differences in work-related values. Sage Publication, USA, p. 327.

10. Hung KH, Li SY, Belk RW (2007) Glocal understandings: female readers' perceptions of the new woman in Chinese advertising. J Int Bus Stud 38 (6): 1034-1051.

11. Till BD, Busler M (2000) The match-up hypothesis: physical attractiveness, expertise and the role of fit on brand attitude, purchase intent and brand beliefs. J Advertising 29(3): 1-13.

12. Reichert T, Heckler SE, Jackson S (2001) The effects of sexual social marketing appeals on cognitive processing and persuasion. J Advertising 30 (1): 13-27.

13. Kim K, Sagas M (2014) Athletic or sexy? a comparison of female athletes and fashion models in sports illustrated swimsuit issues. Gend Issues 31(2): 123-141.

14. Stankiewicz JM, Rosselli F (2008) Women as sex objects and victims in print advertisements. Sex Roles 64(7): 579-589.

15. Reichert T, LaTour MS, Ford JB (2011) The naked truth: revealing the affinity for graphic sexual appeals in advertising. J Advertising Res 51 (2): 436.

16. Dianoux C, Linhart Z (2010) The effectiveness of female nudity in advertising in three European countries. Int Mark Rev 27 (5), 562-578.

17. Zubcevic N, Luxton S (2011) A Comparison of Print Advertisements from Australia and Croatia, Australasian Mark J 19(2): 131-136.

18. Zimmerman A, Dahlberg J (2008) The sexual objectification of women in advertising: a contemporary cultural perspective. J Advertising Res 48(1): 71-79.

19. Nelson MR, Paek HJ (2007) A content analysis of advertising in a global magazine across seven countries: implications for global advertising strategies. Int Mark Rev 24 (1): 64-86.

20. Sugiarto C, Barnier VD (2013) Sexually appealing ads effectiveness on Indonesian customers. European J Bus Manag 5(9): 125-135.

21. Liang B, Runyan RC, Fu W (2011) The effect of culture on the context of ad pictures and ad persuasion : the role of context-dependent and context-independent thinking. Int Mark Rev 28 (4): 412-434.

22. Krippendorf K (2013) Content analysis: an introduction to its methodology. Sage Publication, New York, USA, p. 441.

23. Rust RT, Cooil B (1994) Reliability measures for qualitative data: theory and implications. J Mark Res 31(1): 1-14.

24. Zhang L, Srisupandit P, Cartwright D (2009) A comparison of gender role portrayals in magazine advertising: the United States, China and Thailand. Manag Res News 32(7): 683-700. 